\title{
The Influence of Economic Development on The Wetland Conversion in Java-Bali
}

\author{
By \\ Wahyu Hidayati ${ }^{*}$, Ihda Arifin Faiz \\ Department of Economics and Business SV, Universitas Gadjah Mada \\ ${ }^{*}$ Corresponding Author: whdayati@ugm.ac.id
}

Submission: August 28, 2020; Accepted: March 28. 2021

\begin{abstract}
Agriculture Industry has shown declining contributions towards our economy over recent years. In order to avoid any conversion of wetland resulting from economic expansion, it is suggested that there is a need for control of and policy on such conversion. This research aims to analyze: (1) any impact caused by real GRDP, the number of households, nonclassified hotels, and other types of accommodation businesses, as well as Farmers' Terms of Trade (FToT) on the wetland conversion; (2) annual trend of wetland conversion; and (3) sustainability of food security after implementation of wetland conversion control. The data being analyzed is pooled-data series during 2014-2018 taken from 7 provinces across Java-Bali. The result shows that: the real GRDP has negative and significant impact on wetland conversion; the number of households, non-classified hotels, and other types of accommodation businesses show positive and significant effect; and no impact is seen from FToT. This research also finds that there is an upwards trend in wetland area, at the rate of 40,574 hectares/year, whilst estimated area in 2025 is 3,712,382 hectares. This implies that there has been wetland expansion as opposed to wetland conversion. The result also sees increasing trend of rice surplus, reaching 909,922 tons/year, by which it is projected that in 2025 , the surplus can reach $17,404,632$ tons. Consequently, economic development has to be followed by prudent management of renewable resources, prevention of wetland conversion, and rice import policy.
\end{abstract}

Keywords: Wetland Conversion, Economic Development, Pooled-Data

\begin{abstract}
ABSTRAK
Kontribusi Industri Pertanian terhadap perekonomian, semakin menurun setiap tahunnya. Agar tidak terjadi konversi lahan sawah sebagai konsekuensi dari keberhasilan pembangunan ekonomi, maka perlu adanya pengendalian konversi lahan sawah dan kebijakannya. Tujuan penelitian ini adalah untuk menganalisis: (1) pengaruh PDRB Riil, Jumlah Rumah Tangga, Jumlah Usaha Akomodasi pada Hotel non-Bintang dan Akomodasi Lainnya, dan Nilai Tukar Petani (NTP) terhadap Konversi Lahan Sawah; (2) tren luas konversi lahan sawah setiap tahun; (3) kondisi ketahanan pangan setelah Pengendalian Konversi Lahan Sawah. Analisisnya menggunakan data-panel 2014-2018 dan 7 provinsi di Jawa-Bali. Hasilnya menunjukkan: PDRB Riil berpengaruh negatif dan signifikan, Jumlah Rumah Tangga dan Jumlah Usaha Akomodasi pada Hotel non-Bintang dan Akomodasi Lainnya berpengaruh positip dan signifikan, sedangkan NTP tidak berpengaruh terhadap konversi lahan sawah. Konversi lahan yang dimaksudkan adalah perubahan lahan sawah menjadi non-lahan sawah, yang diproksi dari perubahan luas sawah. Bila perubahannya negatif berarti terjadi konversi tetapi bila positif tidak terjadi konversi. Tren Luas Sawah sebelum konversi, menunjukkan adanya kenaikan rata-rata/tahun $40.574 \mathrm{Ha}$, sedangkan taksiran luas sawah pada tahun 2025 sebesar 3.712.382 Ha. Kenaikan tersebut dapat diartikan tidak terjadi konversi lahan sawah melainkan terjadi pencetakan sawah baru setiap tahun sebesar $40.574 \mathrm{Ha}$. Kemudian tren surplus beras menunjukkan adanya kenaikan rata-rata
\end{abstract}


per tahun sebesar 909.922 Ton, sehingga bisa diperkirakan besarnya surplus beras pada tahun 2025 adalah 17.404.632 Ton. Oleh karenanya, peningkatan pembangunan ekonomi harus disertai dengan pengelolaan sumber-daya yang terbarukan, pencegahan konversi lahan sawah, dan impor beras harus dilakukan secara prudent.

Kata kunci: Konversi lahan-sawah, Pembangunan Ekonomi, Data-PANEL.

\section{INTRODUCTION}

Although Agriculture, Forestry, and Fishing Industry was among the top three contributors to Gross Domestic Product (GDP) during 2014-2018, it's contributing less to the total size of economy in recent years. The biggest contributor to GDP during 2014-2018 was Manufacturing Industry (about 20.5\%). It was followed by Agriculture, Forestry, and Fishing (13.25\%), and Wholesale and Retail Trade, Repair of Motor Vehicles and Motorcycles (13.19\%). Compared to 2014 data, the share of Agriculture, Forestry, and Fishing to the total of GDP in 2018 decreased by $4 \%$ while Manufacturing Industry increased by $47.9 \%$ in the same year. The diminishing contribution of this industry was due to the shrinking area of Indonesian agricultural land. The total area for agriculture in 2014 was 26.9 million hectares and the number dropped by $5.6 \%$ to 34.8 million hectares in 2018 (BPS, 2019). Agricultural land comprises: wetland to grow rice (irrigated and non-irrigated), dry fields devoted for permanent or temporary crops, temporary cropland, and land temporarily lying fallow. Other than farming, land is also for commercial, industrial, residential, and recreational purposes. Several factors determine how land is used: climate, land relief, distribution and density of natural resources; residential and industrial center; economic trend; technology; and culture (Institute, 2013: 11-12). Arsyad (2010: 11) defines economic development as any measure taken by a country to boost its economic activities and improve living standards of its people. The ratio of wetland to farmland, around $21.6 \%$ in the past five years, declined by $12.4 \%$ (BPS, 2015-2020). The shifting ratio suggests conversion of land status from agriculture to non-agriculture has taken place in Indonesia.

According to (BPS, 2019), Wetland for agriculture in Java-Bali, 3.3 million hectares in total, makes up the biggest portion of wetland in Indonesia (42.4\%). Most Javanese wetland is found in East Java (14.3\%) followed by Central Java (12.2\%), and West Java (11.6\%). At the same time, Java-Bali are the two islands where rapid social, economic, political, and cultural development is centered. Consequently, it's increasing demands for land to accommodate various activities and functions, which often require wetland conversion. Land is converted because of its limited supply in the market. The supply of land follows perfectly inelastic curve because land cannot be created more (O'sullivan, 2003: 161). Though there can't be creation of more land, different use of it for different purposes continues to grow and this encourages conversion of land use. Hence, wetland is susceptible to conversion into different uses other than agricultural and it may pose threats to local and national food security. In this regard, the government issued presidential regulation No.59 of 2019 on wetland conversion control (Perpres 2019).

Govindaprasad and Manikandan (2014) argue what stimulates demands for conversion of agricultural land are population growth, economic development, unplanned urban growth, and speculative behavior concerning expected future land uses. Whilst, what motivates supply of agricultural land for sale and conversion into non-agricultural uses are small income from farming, difficulties accessing farm inputs, and shrinking size of agricultural land. Such conversion entails declining area of agricultural land and its outputs. In the long run, it poses a danger to food security. This research focuses on the problem with the decreasing contribution of agriculture to the total area of economy over the years. To prevent more wetland conversion driven by economic development, conversion control and policies are needed. This research aims to analyze: (1) any impact caused by real GRDP, the number of households, non-classified hotels, and other types of accommodation businesses, as well as farmers' terms of trade (FToT) on the wetland conversion; (2) annual trend of wetland conversion; and ( 3 ) sustainability of food security after implementation of wetland conversion control. The expected benefits of this research are: (1) helping policy makers in the field of prevention of converted wetland make sure agriculture can become a leading sector in the economy; (2) helping 
general public by encouraging utilization of wetland to ensure sustainable food security; (3) serving as a reference for other researchers in the same or related fields.

To analyze the effect of independent variables (Real GRDP, the number of households, the number of non-classified hotels and other types of accommodation businesses, and FToT) on the dependent variable (wetland conversion), it's necessary to test hypotheses using a regression model with fixed or random effects estimators. Hypotheses proposed in the research are based on several theories noting the complex and multi-dimensional relationship between economic growth and the environment. Among ideas pointed out in the theories are: (i) effects of scale - a certain extent of economic growth may have negative impact on the environment, where an increase in production and consumption causes an increase in environmental damage, and (ii) effects of industrial composition changes in industrial composition along with economic growth: at first the economy shifted towards industrialization (resulting in the transition of production from agricultural to manufactured goods, aggravating environmental damage), before it changed direction towards service industry, triggered by changes in demand and supply, thus reducing the level of domestic environmental damage (Ishwaran M 2010, 20).

Hypothesis 1: Real Gross Domestic Regional Product have significant and negative effects on the wetland conversion.

Demand for land is derived from demand for outputs of production i.e. goods and services (for example corn, rice, houses, manufactured goods, buildings, etc.). How land market interacts with output market is comparable to chicken and egg situation. It's impossible to decide whether high land price is due to high output price or high output price is caused by high land price (O'sullivan, 2003: 159-161). So far it's believed that interaction between supply and demand on a commodity determines market equilibrium. The increase or decrease in supply and demand will affect equilibrium price and quantity. At an equilibrium point, the market price is at its optimum position generating an equal amount of demand (consumer) and supply (producer) for a product or service. When there is an event where demand raises at any given price, both the equilibrium price and the equilibrium quantity rise. In such event the quantity supplied meets the quantity demanded at higher prices. In other words, when supply remains unchanged but demand increases, price and outputs (traded goods and services) both rise (Mankiw, 2004: 78-79).

Hypothesis 2: The number of households have significant and positive effects on the wetland conversion

Hypothesis 3: The number of non-classified hotels and other types of accommodation businesses have significant and positive effects on the wetland conversion.

FToT measures how well the value of products produced by farmers in comparison to the prices paid by farmers for required agricultural inputs and their household consumption. When there is surplus, farmers receive more than what they have to spend, it's more likely that they will not convert the function of their agricultural land.

Hypothesis 4: Farmers' Terms of Trade (FToT) have significant and positive effects on the wetland conversion.

A previous study by Tsani FA, et al. (2018) investigates major factors affecting farmers in Depok Sleman Yogyakarta in the decision to convert their agricultural land. Such factors are age, level of education, total number of family members, land holding size, income, and the land location. Results of analysis show age of farmers and location of agricultural land have a negative influence on the decision to convert the agricultural land. Whilst, level of education and total number of family members have a positive effect while land holding size and income don't significantly influence the said decision. Another study by Rondhi M, et al. (2018) looks into the inter-relationship between economic value of land and conversion of agricultural land by estimating land economic value for agricultural and non-agricultural purposes in two areas in East Java. The study identifies factors affecting land economic value in both areas for both uses. It reveals that agricultural land produces 
higher economic benefits in rural areas. In contrast, compared to agricultural use, non-agricultural use of land (for housing) in urban areas yields economic benefits seven times higher. A study by Makbul Y, et al. (2019) explores factors driving farmers to sell agricultural land lying close to trans-Java toll road. Regarding wetland conversion, the study warns of its major impact on food security. Therefore, measures are needed to make farmer' groups more attractive and to improve livelihood of rural communities. Similar to the aforementioned studies, this research looks into land conversion from agricultural to non-agricultural uses along with internal and external factors driving the conversion. However, unlike the previous studies, this research mainly focuses on wetland (thus leaving out other types of agricultural land i.e. dry fields devoted for permanent or temporary crops, temporary cropland, and land temporarily lying fallow), examines factors influencing wetland conversion, and makes an analysis from macroeconomic perspective.

\section{METHODS}

The operational definitions of variables in this research are: (1) Gross Regional Domestic Product (GRDP) and Gross Domestic Product (GDP) are economic indicators representing the value of all final goods and services produced within a region or a country in a given period of time (Rp million); (2) Real GRDP is 2010 GRDP at constant prices, which is useful for measuring more accurately the rate of economic growth of an area without any of the distorting effects of inflation (Rp million); (3) household is a person or group of people living under the same roof and eating from the same kitchen, in other words, their daily needs are managed together as a unit (000 units); (4) An accommodation business is a business providing lodging services that can be complemented with other tourism services. Types of accommodation are hotels, villas, guesthouses, campsites, caravan stops, and other facilities wherein a tourist can stay and receives other services (unit); (5) FToT is a comparison between the index of prices received and the index of prices paid by farmers. FToT compares the price farmers receive for agricultural products they produce with the price paid by farmers for required agricultural inputs and their household consumption (ratio); (6) wetland is an area of wet and/or dry agricultural land flooded periodically and/or continuously planted with rice and/or interspersed with other seasonal crops (hectares); (7) wetland conversion is a change in the function of a paddy field from agricultural to non-agricultural use, permanently or temporarily (hectares); (8) a change in total wetland area within the observed period (2014-2018) is used as a proxy for assessing the total area of converted wetland; a negative change means more wetland areas are converted, and a positive change signifies more wetland areas are made (in hectares); (9) wetland conversion control is a series of activities intended to manage permanent or temporary conversion of land from agricultural to nonagricultural use (in line with presidential regulation No.59 of 2019 concerning control over wetland conversion).

The analytical tools used in this research are Descriptive Statistics, and Pooled-data Regression Model. The data analyzed is secondary data series during 2014-2018, taken from 7 provinces across Java-Bali (DKI Jakarta, West Java, Central Java, DIY, East Java, Banten, and Bali), and respective to this research problem and goal. Linear-Trend, to determine the average increase in wetland conversion and the estimated annual rice surplus/deficit. Data on rice consumption and production was used to determine the sustainability of food security after implementation of wetland conversion control in Java-Bali. The research employed semi-log models regression for pooled-data analysis with fixed or random effects estimators. Widarjono (2016: 353-366) claims the use of pooled-data offers several advantages: (1) pooled-data combining time series data and cross section data will generate more data and create a greater degree of freedom; (2) combination of time series data and cross section data will eliminate problems with omitted variables. Semi-log model is considered important because the independent variable data has a large variability. Large variability can be smooth by logging it while the dependent variable has small data variations

The regression equation model:

$$
\text { AFLS }_{i t}=\beta_{0}+\beta_{1} \operatorname{lnPDRB}_{i t}+\beta_{2} \operatorname{lnJRT} T_{i t}+\beta_{3} \operatorname{lnJAHAL_{it}}+\beta_{4} N_{N T P} i t+e_{i t}
$$

Notation: 
The Influence of Economic .... (Hidayati \& Faiz.)

\begin{tabular}{|c|c|}
\hline AFLS it & $=$ Size of conversion wetland in Java-Bali i in year $t$ (hectares) \\
\hline InPDRBit & $\begin{array}{l}=\text { Real Gross Regional Domestic Product of provinces in Java-Bali i in year } \\
\text { t (Rp million) }\end{array}$ \\
\hline InJRTit & $\begin{array}{l}=\text { the number of households in provinces in Java-Bali i in year t (000 } \\
\text { units) }\end{array}$ \\
\hline InJAHALit & $\begin{array}{l}=\text { the number of non-classified hotels and other types of } \\
\text { accommodation businesses in provinces in Java-Bali } i \text { in year } t \text { (unit) }\end{array}$ \\
\hline NTPit & $=$ FToT in Java-Bali i in year $\mathrm{t}$ \\
\hline$\beta 0$ & $=$ Constant \\
\hline
\end{tabular}

$\beta 1<0, \beta 2, \beta 3, \& \beta 4>0=$ coefficient

eit $\quad=$ error term

\section{RESULTS AND DISCUSSIONS}

A selection test was done to determine the most suitable model among CEM, FEM, and REM as shown in diagram 1:

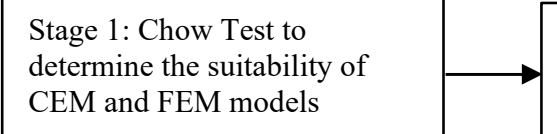

Chow Test

$\mathrm{H}_{0}$ : CEM model is suitable

$\mathrm{H}_{\mathrm{a}}$ : FEM model is suitable
Stage 2: Hausman Test to determine the suitability of REM and FEM models

\section{Hausman Test}

$\mathrm{H}_{0}$ : REM model is suitable

$\mathrm{H}_{\mathrm{a}}$ : FEM model is suitable
Stage 3: Lagrange Multiplier Test to determine the suitability of CEM and REM models

Lagrange Multiplier Test

$\mathrm{H}_{0}$ : CEM model is suitable

$\mathrm{H}_{\mathrm{a}}$ : REM model is suitable

Diagram 1. Selection of the most suitable model

As shown in diagram 1, F-statistic test which is a test of the residual sum of squares was conducted to select between Common Effect/Pooled Square and Fixed Effect (Chow Test). In such test, if calculated F-value is larger than F-table at a certain confidence level $(\alpha), H_{0}$ must be rejected and Fixed Effect Model should be selected, and vice versa. The Hausman test was used to select between Random Effect Model (REM) and Fixed Effect Model (FEM). In this kind of test, if the calculated F-value is larger than F-table at a certain confidence level $(\alpha), H_{0}$ is rejected and FEM should be chosen, and vice versa. The Lagrange Multiplier test was used to decide between Common Effect Model (CEM) and REM. In such test, if the Breusch-Pagan cross-section value is below a certain confidence level $(\alpha), H_{0}$ is rejected and REM should be used, and vice versa. Results of estimation using linear-log models regression for pooled-data analysis with fixed and random effects estimators on Real GRDP, the number of households, the number of non-classified hotels and other types of accommodation businesses, and FToT are stated in table 1.

Table 1. Results of Estimation Using Common Effect, Fixed Effect, and Random Effect Models

\begin{tabular}{llcc}
\hline Dependent Variable & \multicolumn{3}{l}{ LS } \\
\hline Independent Variables & Common Effect & Fixed Effect & Random Effect \\
\hline Constants & -2421293. & 3369602. & -2980562. \\
LnPDRBRIIL & $-118156.6^{*}$ & 289426.7 & $-149286.7^{*}$ \\
LnJRT & $534181.6^{*}$ & -814619.0 & $569386.7^{*}$ \\
LnJAHAL & $137772.4^{*}$ & -11900.76 & $40010.11^{* *}$ \\
NTP & -8861.368 & 1003.692 & 4336.231 \\
\hline
\end{tabular}

Source: processed Output Data

Note: ${ }^{*}$ ) significant at $\alpha 0.05 ;{ }^{* *}$ ) significant at $\alpha 0.10$

Table 2. Chow Test

\begin{tabular}{llcl}
\hline Effects Test & Statistic & d.f. & Prob. \\
\hline Cross-section F & 28.500869 & $(6,24)$ & 0.0000 \\
Cross-section Chi-square & 73.324037 & 6 & 0.0000 \\
\hline
\end{tabular}




\section{Source: Processed Output Data}

Table 2. shows results of Chow Test where the F probability value is 0.0000 , below the degree of error $(\alpha 0,05)$. It leads to rejection of $\mathrm{H}_{0}$ or acceptance of $\mathrm{H}_{\mathrm{a}}$, meaning Fixed Effect Model is more suitable to use than Common Effect Model (PLS). The next table displays results of Hausman Test to choose between Fixed Effect Model and Random Effect Model.

Table 3. Hausman Test

\begin{tabular}{lccl}
\hline Test Summary & Chi-Sq. Statistic & Chi-Sq. d.f. & Prob. \\
\hline Cross-section random & 7.590111 & 4 & 0.1078 \\
\hline
\end{tabular}

Source: Processed Output Data

As shown in table 3., the probability value of random cross-section of 0.1190 is above the degree of error $(\alpha 0,05)$, resulting in acceptance of $\mathrm{H}_{0}$. Therefore, Random Effect is a better model than Fixed Effect. Table 4 displays results of Lagrange Multiplier Test.

Table 4. Lagrange Multiplier Test

\begin{tabular}{lcrr}
\hline Null (no rand. effect) Alternative & Cross-section One-sided & Period One-sided & \multicolumn{1}{c}{ Both } \\
\hline Breusch-Pagan & 50.92426 & 1.480199 & 52.40446 \\
& $(0.0)$ & $(0.2237)$ & $(0.0000)$ \\
Honda & 7.136123 & -1.216634 & 4.185711 \\
& $(0.0)$ & $(0.8881)$ & $(0.0000)$ \\
King-Wu & 7.136123 & -1.216634 & 3.570880 \\
& $(0.0)$ & $(0.8881)$ & $(0.0002)$ \\
GHM & -- & -- & 50.92426 \\
& -- & -- & $(0.0000)$ \\
\hline
\end{tabular}

\section{Source: processed Output Data}

Based on Lagrange Multiplier Test on Table 4., $\mathrm{H}_{0}$ is rejected because, as displayed in the above table, Breusch-Pagan statistic for cross-sectional value is 0.0000 , below the degree of error $(\alpha=0.05)$. Thus, Random Effect is a more precise model than the Common Effect.

The influence of real gross regional domestic product, the number of households, the number of non-classified hotels and other types of accommodation businesses, and FToT on wetland conversion

To analyze the factors influencing conversion of wetland, Random Effect - the best model selected for the research - is used in the following linear-log regression equation.

$$
\begin{aligned}
& A F L S_{i t}=-2980562 .-149286.7 \operatorname{lnPDRBRL} \mathrm{it}^{*}+569386.7 \operatorname{lnJRT}_{\mathrm{it}}{ }^{*}+40010.11 \operatorname{lnJAHAL}_{\mathrm{it}}{ }^{* *}+4336.231 \mathrm{NTP}_{\text {it }} \\
& R^{2}=0,754489 ; \operatorname{Adj} R^{2}=0,721754 ; \text { Prob. (F-statistic) }=0,00000 \\
& \text { Notes: }{ }^{*} \text { ) significance level of } \alpha 0,05 \\
& { }^{* *} \text { ) significance level of } \alpha 0,10
\end{aligned}
$$

The sign test (a priori hypotheses) of all independent variables indicates they are in accordance with all the hypotheses. It shows real GRDP has negative and significant effects on wetland conversion. A change in total size of wetland within the observed period (2014-2018) is used as a proxy for assessing the total area of converted wetland. A negative change means shrinking wetland areas and a positive change signifies expanding wetland areas (in hectares). The number of households, nonclassified hotels and other types of accommodation businesses areas are all independent variables that have positive and significant effect, whilst FToT has no significant effect on wetland conversion. As FToT measures the ability of exchange value of commodity needed by the farmers, although the average result shows $103(>100)$, however, this does not provide adequate impact on wetland conversion.

The coefficient of Real GRDP of -149286.7 has a ceteris paribus interpretation. If real GRDP increases by $1 \%$, wetland conversion will decrease by 49.3 thousand hectares and vice versa (that's 
good condition). The proportion of the variance $R^{2}$ which is 0.754489 means that $75 \%$ of the variation of the independent variable can be used to explain the variation in the dependent variable, while the remaining $25 \%$ is influenced by other variables outside the model used in the research such as capital, labor skills, technology, or irrigation system. A study by Riekhof MC, at al. (2019) indicates potential trade-offs between goals of sustainable development. The study also suggests policies focusing on resource use or trade (international trade ban or certified trade) are not sufficient to prevent exhaustion of resources. Nuryartono N, et al. (2017) argue that major factors contributing to land conversion are mostly related to development, such as an increase in the number of settlements and regional economic development. Since there is a trade-off between economic development and land use, economic development policies should take account of prevention of wetland conversion. A study by Rahardian R, and Zarkasi IF (2019) examines local community's resistance to the construction of a cement factory in Kayen, Pati, Central Java, fueled by fear of increasing pollution, contamination and depletion of water sources, loss of agricultural land and employment opportunities, and spread of diseases. Putra PTN, et al. (2019), investigate how macroeconomic indicators (GDP, trades, energy consumption and exchange rates) relate to carbon dioxide emissions in four ASEAN countries (Indonesia, Malaysia, Philippines, and Thailand). Results of their study indicate GDP is a variable having the largest contribution to the dynamics of carbon dioxide emissions in four ASEAN countries. A study by Nurpita A, et al. (2017) delves into the impact of land conversion on farmers' income and their food security status. The results show land conversion has a negative and significant effect on their income. Conversion of land as part of the construction of YIA (Yogyakarta International Airport) has forced some farmers to sell a parcel of or even the entirety of their agricultural land.

The coefficient of number of household - which is 569386.7 - can be interpreted as follows: if the number of households increases by $1 \%$, ceteris paribus, the wetland conversion will increase by 569.4 thousand hectares and vice versa, but wetland area will decrease caused by land use for households. The ceteris paribus interpretation of the coefficient of the number of non-classified hotels and other types of accommodation businesses - which is 40010.11 - is that if the number of accommodation businesses increases by $1 \%$, the wetland conversion will increase by 40 thousand hectares and vice versa, caused by land use for accommodation businesses. Both the number of households (JRT) and the number of non-classified hotels and other types of accommodation businesses (JAHAL) have a positive effect on the wetland conversion. The variable JRT represents the final consumers of rice (people buying rice mostly for their own use), while JAHAL represents business consumers that buy rice for resale to their customers. The interaction between rice consumption and rice production in the market displays a typical relationship between demand and supply. If there is an increase in demand for rice, there will be a new market equilibrium with higher equilibrium price and quantity. An increase in rice production will indicate increase in wetland area, will decrease the wetland conversion and vice versa, because rice production is equal to the area of wetland multiplied by the productivity of the land (Production = Rice Area $x$ Productivity). At a given level of productivity, if rice production increases - ceteris paribus - wetland area will increase. What affects rice production as suggested by Bashir A, and Yuliana S (2018) are human capital, labor, wages, urban population, and price of rice. Moreover, rice consumption is affected by human capital, per capita income, population, and consumption the previous year. In his study, Poernomo A (2017) argues that government policies are protective towards both ends of rice production capability (the government subsidize agricultural inputs and control domestic rice prices) that farmers are able to maintain profitable rice production at market prices but sell the output at a profit rate $64 \%$ higher than the level of social prices. Putri, et al. (2015) indicate the size of residential area, the number of industries, GRDP, and the length of roads have a positive and significant effect on the conversion of agricultural land. They also argue that the total population and the total investment do not have a significant effect on land conversion in 29 districts, but they do in certain cities. The total population, the size of residential area, the number of industries, and GRDP have a positive and significant effect on the conversion of agricultural land in 6 cities. Meanwhile, the total length of roads and the total investment do not have a significant effect. A study by Canon S, et al. (2018) shows while the use of labor and the size of wetland have a positive 
and significant effect on rice production, the use of farming technology does not significantly affect rice production.

\section{The Trend in Wetland Area Annually}

The average of total wetland area in Java-Bali during $2014-2018$ was 478,173 hectares with the largest area at 1.3 million hectares and the smallest at 451 hectares. East Java had the largest portion of wetland area (14.3\%) followed by Central Java (12.2\%), and West Java (11.6\%). Most wetland area in Indonesia is found in Java-Bali because of the following: favorable land fertility, suitable climate, good irrigation systems as exemplified by subak - Balinese water management system, and other advantages unique to Java-Bali. The last five years saw an increase and decrease in the total size of wetland area, but an expansion of wetland area has been recorded in three aforementioned provinces. Estimates of annual changes in the total size of wetland area were made by using a least squares regression line as shown in table 5.

Table 5. Least Square Method to Estimate Trend in the Wetland Area in Java-Bali 2014-2018 (Hectares)

\begin{tabular}{ccccc}
\hline Year & Wetland Size $(\mathrm{Y})$ & $\mathrm{X}$ & $\mathrm{XY}$ & $\mathrm{X}^{2}$ \\
\hline 2014 & $3,325,049$ & -2 & $(6,650,098)$ & 4 \\
2015 & $3,299,424$ & -1 & $(3,299,424)$ & 1 \\
2016 & $3,298,444$ & 0 & - & 0 \\
2017 & $3,271,042$ & 1 & $3,271,042$ & 1 \\
2018 & $3,542,111$ & 2 & $7,084,222$ & 4 \\
\hline Total & $16,736,070$ & & 405,742 & 10 \\
\hline
\end{tabular}

Source: BPS, Statistik Indonesia 2015-2020

Trend Equation: $Y^{\prime}=a+b X$

$\mathrm{a}=\Sigma \mathrm{Y} / \mathrm{n}$ and $\mathrm{b}=\Sigma \mathrm{XY} / \mathrm{X}^{2}$

$a=16.736 .070 / 5=3.347 .214$

$\mathrm{b}=405.742 / 10=40.574$

$\mathrm{Y}^{\prime}=3.347 .214+40.574 \mathrm{X}$

$\mathrm{a}=$ Estimated wetland area in mid-2016 (base year) of 3,347,214 hectares

$b=$ average increase in wetland area annually, which is 40,574 hectares

$Y^{\prime} 2025 \rightarrow$ scale $X=9$

$Y^{\prime} 2025=3.347 .214+40.574 X \rightarrow Y^{\prime} 2025=3.347 .214+40.574(9)=3.712 .382$

Results of running the above equation on data in table 5 . show there was an annual increase in the wetland area within the observed period by 40,574 hectares and estimated size of wetland area by 2025 is 3.71 million hectares. The wetland area increase indicates wetland conversion didn't take place in the last five years and the trend is expected not to change course until 2025. The increase also implies wetland area is expanding in size instead of shrinking at the rate of 40,574 hectares per year. This may be the outcome of institution of an integrated team for wetland conversion control at regional and central government levels, which is already active in the last five years. It illustrates commitment of the government to prevent wetland conversion often accompanying rapid economic development and to ensure sustainability of national food security. Presidential regulation number 59 of 2019 provides a legal basis for control of agricultural land conversion. One of measures to control such conversion is Article 20 of the regulation arranges provision of incentives to those who own/manage agricultural land situated within Map of Protected Agricultural Land (defined in article 15). Article 20 also stipulates that the incentives are extended in the form of: a) agricultural facilities and infrastructure; b) irrigation facilities and infrastructure; c) streamlined process of land certification; and/or d) other forms in accordance with the provisions of laws and regulations. Table 6 displays the declining size of wetland area in Indonesia each year. Among factors influencing the decline are: economic growth, the need for land to accommodate various increasingly-complex activities, the increasing market value of land situated within commercial zones, and so on. 
Table 6. Least Square Method to Estimate Trend in the Size of Wetland Area in Indonesia 2014-2018

\begin{tabular}{ccccc}
\hline Year & Wetland Size $(Y)$ & $X$ & $X Y$ & $X^{2}$ \\
\hline 2014 & $8,111,593$ & -2 & $(16,223,186)$ & 4 \\
2015 & $8,092,907$ & -1 & $(8,092,907)$ & 1 \\
2016 & $8,187,734$ & 0 & - & 0 \\
2017 & $8,164,045$ & 1 & $8,164,045$ & 1 \\
2018 & $7,105,145$ & 2 & $14,210,290$ & 4 \\
\hline Total & $39,661,424$ & & $(1,941,758)$ & 10 \\
\hline
\end{tabular}

Source: BPS, Statistik Indonesia 2015-2020

Trend Equation: $Y^{\prime}=a+b X$

$\mathrm{a}=\Sigma \mathrm{Y} / \mathrm{n}$ and $\mathrm{b}=\Sigma \mathrm{XY} / \Sigma \mathrm{X}^{2}$

$\mathrm{a}=39.661 .424 / 5=7.932 .285$

$\mathrm{b}=(1,941,758) / 10=(194.176)$

$\mathrm{Y}^{\prime}=7.932 .285+(194,176) \mathrm{X}$

$\mathrm{a}=$ Estimated wetland area in mid-2016 (base year) of 7,932,285 hectares

$\mathrm{b}=$ average decrease in wetland area annually, which is $194,176 \mathrm{Ha}$.

$Y^{\prime} 2025 \rightarrow$ scale $X=9$

$Y^{\prime} 2025=7.932 .285+(194.176) X \rightarrow Y^{\prime} 2025=7.932 .285+(-194.176)(9)=6,184,703$

Table 6. calculation results show the average decrease in the size of Indonesian wetland area at 194,176 hectares annually. In contrast to intensification and extensification of wetland area in JavaBali through control of wetland conversion, portions of agricultural land outside Java-Bali have been converted into non-agricultural uses. Because of wetland area in Indonesia decreases at an average pace of 194,176 hectares per year, it's projected that by 2025 the total size of Indonesian wetland declines to only 6.185 million hectares. When this 2025 projection is compared to the total size of wetland area in 2014 which was 8.112 million hectares, wetland area loss within a span of 11 years (2014-2025) is expected to reach 1.927 million hectares. In their study Makbul Y, et. al. (2019) urge farmers not to give up their agricultural land for conversion. They also recommend improvement to agricultural environment and betterment of life in rural communities. To ensure successful development of wetland in the future, Sulaiman AA, et al. (2019) propose three key factors: land-soilwater characterization, landscape and land use design, and community development. Another study by Tsani FA, et al. (2018) suggests the age of farmers and where the agricultural land is situated have a negative effect on the decision to convert agricultural. However, education level and total number of family members affect positively but land holding size and income do not significantly influence decision to give up agricultural land for conversion. A study by Purnami SAA, and Santini MM (2017) indicates population growth has a positive and significant effect on agricultural land conversion. Although population growth does not have a significant effect on the sustainability of subak (wetland irrigation system in Bali), conversion of agricultural land has a negative and significant effect on its sustainability. Rondhi M, et al. (2018) point out that agricultural land produces higher economic benefits in rural areas. In contrast, compared to agricultural use, non-agricultural use of urban land (for residential area) yields economic benefits seven times higher. Agricultural land, they add, returns higher yield after conversion.

\section{Sustainability of Food Security after Implementation of Wetland Conversion Control}

Food security refers to a condition where people have physical, social, and economic access to sufficient food and domestic rice production meets domestic needs for rice without resorting to imports. However, the government still needs to import rice which acts as a buffer against scarcity of rice on the market due to crop failure, peak demand for rice in anticipation of religious holidays, and speculations (unscrupulous act of rice hoarding). Yet, rice imports must be carried out prudently so as not to flood the market and place domestic farmers at a disadvantage. To anticipate a spike in rice 
demand and supply and to ensure price stability, The Indonesia Logistics Bureau often carries out market operations.

Table 7. Population, Rice Consumption-Production, and Surplus in Java-Bali 2014-2018

\begin{tabular}{cccccc}
\hline Year & $\begin{array}{c}\text { Population } \\
\text { (People) }\end{array}$ & $\begin{array}{c}\text { Rice Consumption/ Rice Consumption } \\
\text { person/year }(\mathrm{Kg})\end{array}$ & $\begin{array}{c}\text { Rice Production } \\
\text { (Ton) }\end{array}$ & $\begin{array}{c}\text { Surplus (P-C) } \\
\text { (Ton) }\end{array}$ & (Ton) \\
\hline 2014 & $56,104,900$ & 183.98 & $4,616,243$ & $9,278,070$ & $4,661,827$ \\
2015 & $147,362,100$ & 563.04 & $11,835,225$ & $22,672,749$ & $10,837,524$ \\
2016 & $149,236,800$ & 558.24 & $11,967,164$ & $22,351,836$ & $10,384,672$ \\
2017 & $150,820,700$ & 544.20 & $11,711,836$ & $22,836,730$ & $11,124,894$ \\
2018 & $152,369,800$ & 565.20 & $12,186,511$ & $21,254,263$ & $9,067,752$ \\
\hline Average & $131,178,860$ & 482.93 & $10,463,396$ & $19,678,730$ & $9,215,334$ \\
\hline
\end{tabular}

Source: BPS, other publications

Table 7. provides information about annual rice production and consumption in Java-Bali (20142018). With a population of 131.18 million people, Java-Bali produced 19.68 million tons/annum on average, higher than the average consumption/year of 10.46 million tons, leaving a surplus of 9.22 million tons. The rice surplus, expected to last for the next few years, can be used to meet rice needs in other areas outside Java-Bali. Analysis of yearly rice surplus trend is shown in table 8.

Table 8. Calculation of Rice Surplus Trend in Java-Bali from 2014 to 2018 (in tons) Using the Least Square Method

\begin{tabular}{ccccc}
\hline Year & Rice Surplus $(Y)$ & $X$ & $X Y$ & $X^{2}$ \\
\hline 2014 & $4,661,827$ & -2 & $(9,323,654)$ & 4 \\
2015 & $10,837,524$ & -1 & $(10,837,524)$ & 1 \\
2016 & $10,384,672$ & 0 & - & 0 \\
2017 & $11,124,894$ & 1 & $11,124,894$ & 1 \\
2018 & $9,067,752$ & 2 & $18,135,505$ & 4 \\
\hline Total & $46,076,669$ & & $9,099,220$ & 10 \\
\hline
\end{tabular}

Source: Table 7.

Trend Equation: $Y^{\prime}=a+b X$

$\mathrm{a}=\sum \mathrm{Y} / \mathrm{n}$ and $\mathrm{b}=\sum \mathrm{XY} / \Sigma \mathrm{X}^{2}$

$\mathrm{a}=46.076 .669 / 5=9.215 .334$

$b=9.099 .220 / 10=909.922$

$Y^{\prime}=9.215 .334+909.922 X$

$\mathrm{a}=$ Estimated rice surplus in mid-2016 (base year) of 9,215,334 tons.

$b=$ The average increase in rice surplus every year, which is 909,922 tons.

$Y^{\prime} 2025 \rightarrow$ scale $X=9$

$Y^{\prime} 2025=9.215 .334+909.922 X \rightarrow Y^{\prime} 2025=9.215 .334+909.922(9)=17.404 .632$

Table 8. shows the estimated rice surplus/year is 9.22 million tons on average with an increase in annual surplus of 909.9 thousand tons on average. Therefore, it can be estimated that rice surplus by 2025 is 17.41 million tons. It means that food security may remain intact provided that the following measures are continuously taken: controlling wetland conversion, increasing agricultural productivity, upgrading irrigation system, improving milling yields of polished grain, etc. It concurs with Aprillya MR, et al. (2019) who claim better rice harvesting procedures and increased milling yields will improve rice production which, in turn, will help food security. Rosyandi AN, et al. (2019) add that farmers make significantly better income selling polished rice grains rather than unpolished rice kernels. A calculation using Hayami method shows there is an added value of Rp786.00 per kilogram where $86 \%$ of added 
value goes to farmers and $14 \%$ to direct labors. The Revenue/Cost $(\mathrm{R} / \mathrm{C})$ ratio of rice kernels is 1.57 while the $\mathrm{R} / \mathrm{C}$ ratio of polished rice grains is 1.68 .

\section{CONCLUSIONS}

Based on the analysis and discussion, this study came to the following conclusions: (1) REM is the best model to use with linear regression estimation to analyze the factors affecting wetland conversion. The sign test of all independent variables indicates they are in accordance with all the hypotheses. The independent variable that has significant and negative effect on wetland conversion is real GRDP, that have significant and positive effect are the number of households and the number of non-classified hotels and other types of accommodation businesses, whilst FToT has no significant effect on wetland conversion. $R^{2}$ is 0.754489 . A change in total wetland area within the observed period (2014-2018) is used as a proxy for assessing the total area of converted wetland; a negative change means more wetland areas are converted, and a positive change signifies more wetland areas are expanded. (2) The trend of wetland area in Java-Bali during 2014-2018 shows there was an annual increase in the wetland area by 40,574 hectares and estimated of wetland area by 2025 is 3.71 million hectares. The increase suggests wetland conversion didn't take place in the last five years and the trend is expected to continue to 2025. The increase also indicates wetland area is expanding in area the rate of 40,574 hectares per annum. This happens because since 2014-2018 has been an Integrated Team for Control of Wetland Conversion at the local and central government level which is strengthened by the issuance of Perpres No.59/2019 on Controlling the Wetland Conversion. (3) The rice surplus trend shows the estimated average surplus is 9.22 million tons per year with an average increase in surplus of 909.9 thousand tons per annum. Therefore, it's projected that rice surplus by 2025 is 17.41 million tons. Thus, the future of national food security isn't under threats provided that these measures are continuously done to ensure increased rice production: controlling wetland conversion, increasing agricultural productivity, upgrading irrigation system, improving milling yields (milling yield of polished grain), and so on.

Limitations in this study: data for 2019 wasn't included in the data set used in the analysis because of an outlier due to variability in the measurement criteria. For example, the criteria for measuring the size of protected agricultural land have been changing for years. In addition, some of the data was very preliminary.

The policy implications in this study: (1) economic growth must be accompanied by a serious management of renewable resources, including wetland; (2) to prevent conversion of agricultural land, it's necessary to implement more intensively presidential regulation number 59 of 2019 concerning control of wetland conversion at regional and central government levels; (3) To ensure effectiveness of buffer stock system maintained by the Indonesia Logistics Bureau for force majeure conditions, rice imports must be carried out prudently.

\section{ACKNOWLEDGEMENT}

We thank you very much, dear Mr. Akhmad Akbar Susamto, SE., M.Phil., Ph.D., for his direction and correction to this research proposal so that it was included in regular scheme in the SV UGM Department of Economics and Business. Thank you also to colleagues: Kun Haribowo, Yudistira, Amalia Sumbadha, Fahri, and Dapit, for their discussions on the improvement of this journal article. May it be useful.

\section{REFERENCES}

Aprillya MR, Suryani E, Dzulkarnain A. (2019). System Dynamics Simulation Model to Increase Paddy Production for Food Security. Journal of Information Systems Engineering and Business Intelligence. Vol. 5. No. 1. 67-75.

Arsyad, Lincolin. (2010). Ekonomi Pembangunan. Yogyakarta: BPFE. 
Bashir A, Yuliana S. (2018). Identifying Factors Influencing Rice Production and Consumption in Indonesia. Jurnal Ekonomi Pembangunan: Kajian Masalah Ekonomi dan Pembangunan Vol. 19.No. 2. 172-185.

BPS. (2019). Statistik Indonesia 2019. Jakarta: BPS.

BPS. (2020). Provinsi Dalam Angka 2015-2020 dan Statistik Indonesia 2020. Jakarta: BPS

Canon S, Halid A, and Daud F. (2018). The Influence of Labor and Land Use Management on Rice Farming Production in Pohuwato Distric Gorontalo. Jurnal Perspektif Pembiayaan dan Pembangunan Daerah Vol. 5. No. 4. 37-347.

Govindaprasad PK, and Manikandan K. (2014). Agricultural Land Conversion and Food Security: A Thematic Analysis. International Research Journal of Agriculture and Rural Development Vol. 3. No. 1. 1-18.

Ishwaran M, Ansaloni GP, Rubin A. (2010). Economic Growth and The Environment. (Department for Environment Food and Rural Affairs) 2.

Institute, Appraisal. (2013). The Appraisal of Real Estate. 14 ${ }^{\text {th }}$ edition. USA: an Illinois.

Makbul Y, Ratnaningtyas S, and Pradono. (2019). Factors Influences Farmers Desire to Agricultural Land Conversion in Indonesia using Structural Equation Model Analysis. International Journal of Engineering \& Technology 8 (1.10): 71-74.

Mankiw, NG. 2004. Principles of Microeconomics. Third Edition. USA: Thomson.

Nurpita A, Wihastuti L, and Andjani YI. (2017). The Impact of Land Conversion on Income and Food Security Status for Farmer Households in 5 Villages in Temon Sub-District, Kulon Progo District. JKAP (Jurnal Kebijakan dan Administrasi Publik). Vol. 21. No. 2. 180-188.

Nuryartono N, Tonggato A, Yusdiyanto A, Pasaribu SH, and Anggraenie T. (2017). Land Conversion and Economic Development in Jawa Barat Province: Trade off or Synergy? IOP Conf. Earth and Environmental Science 54: 1-10.

O'sullivan. (2003). Urban Economics. Vol. $5^{\text {th }}$ edition. New York: McGraw-Hill/Irwin.

Poernomo, A. (2017). Analysis of The Protection of Input Subsidies Policy (Fertilizer and Seed) and Production Output in Rice Plant Agriculture in Indonesia. EKO-REGIONAL. Vol. 12 No. 1. March. 49-55.

Purnami SAA, Santini MN. (2017). The Impact of Population Growth to the Agricultural Land Conversion and Sustainability of Subak as World Cultural Heritage. IOSR Journal of Humanities and Social Science (IOSR-JHSS). Vol. 22. No. 8. 13-18.

Putra PTN, Yuliati L, and Lestari EK. (2019). An Empirical Study of Climate Change on Carbon Dioxide Emission in ASEAN 4: Vector Autoregression Exogenous (VARX) Approach. EKO-REGIONAL. Vol. 14. No. 2. 109-120.

Putri, Rosalia, Zara. (2015). Analisis Penyebab Alih Fungsi Lahan Pertanian ke Lahan Non-Pertanian Kabupaten/Kota di Provinsi Jawa Tengah 2003-2013. EKO-REGIONAL. Vol. 10. No. 1. 17-22.

Rahardian R, and Zarkasi, IF. (2019). Policy Advocacy in Resolving an Environmental Preservation Conflict: A Case of Policy Advocacy between The Government, Private Sector and Society in Kayen, Pati, Central Java. JKAP (Jurnal Kebijakan dan Administrasi Publik). Vol. 23. No. 2. 154170.

Riekhof MC, Regnier E, and Quaas M. (2019). Economic Growth, International Trade, and The Depletion or Conservation of Renewable Natural Resources. Journal of Environmental Economics and Management. Vol. 97. September. 116-133.

Rondhi M, Pratiwi AP, and Handini TV. (2018). Agricultural Land Conversion, Land Economic Value, and Sustainable Agriculture: A Case Study in East Java, Indonesia. Land. Vol. 7. No. 148. 1-19.

Rosyandi AN, Supadi, and Windhani K. (2019). Rice Selling Vs Grain Selling Farms: Which One is More Profitable? EKO-REGIONAL. Vol. 14. No. 1. 57-64.

Sulaiman AA, Sulaeman Y, and Minasny B. (2019). A Framework for The Development of Wetland for Agricultural Use in Indonesia. Resources. Vol. 8. No. 34. 1-16.

Tsani FA, Purwaningsih Y, and Daerobi A. (2018). Farmer's Decision in Converting the Function of Agricultural Lands. Jurnal Ekonomi Pembangunan: Kajian Masalah Ekonomi dan Pembangunan. Vol. 19. No. 1.1-11. 
The Influence of Economic .... (Hidayati \& Faiz.)

Widarjono, Agus. (2016). Ekonometrika Pengantar dan Aplikasinya. Edisi Keempat. Yogyakarta: UPP STIM YKPN.

Wyatt, Peter. (2007). Property Valuation: in an economic context. Oxford: Blackwell Publishing.

(2019). Peraturan Presiden Republik Indonesia No.59 Th.2019 tentang Pengendalian Alih Fungsi Lahan Sawah. Indonesia. 